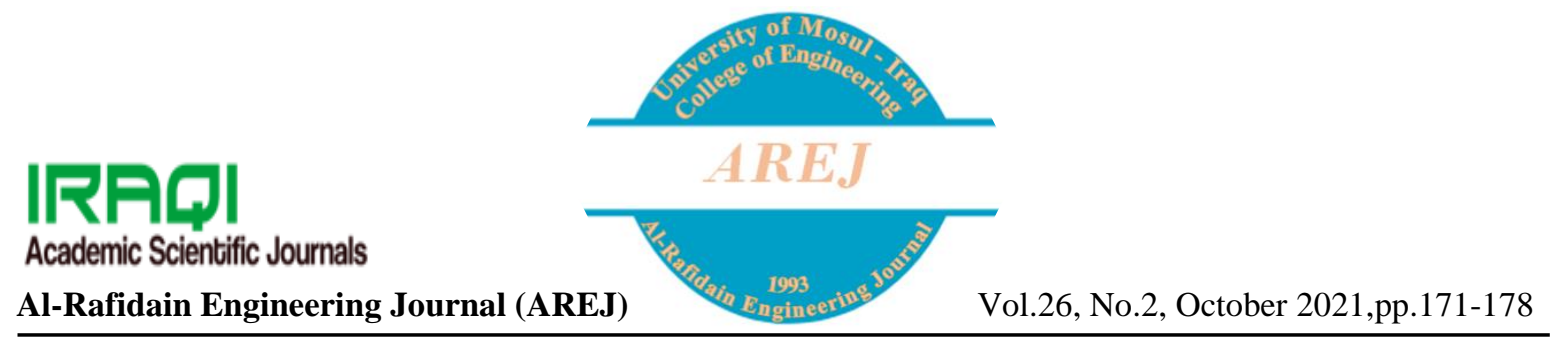

\title{
Simulation of High Efficiency Tandem Solar Cell using InGaP/GaAs
}

\author{
Marwah M. Salim \\ marwa.salim20192019@stu.uoninevah.edu.iq
}

\author{
Khalid Kh. Mohammed \\ khalid.khaleel@uoninevah.edu.iq
}

Electronic Engineering Department, Nineveh University, Mosul, Iraq

Received: 27/6/2021

Accepted: 16/8/2021

\begin{abstract}
The dual junction (tandem) cell structure (InGaP/GaAs) is depending on Indium gallium Phosphides (InGaP) as the upper cell, Gallium Arsenide (GaAs) as the lower cell, and behaves as tunnel junction (TJ). The structure of the (InGaP/GaAs) dual junction cell was simulated in this work using SILVACO program to obtain a high solar cell efficiency. Firstly, the effect of doping concentration and thickness of window layer of the upper cell was investigated on the (InGaP/GaAs) tandem cell performance. Then the GaAs /GaAs (TJ) is replaced by an InGaP/GaAs (TJ).A comparison of performance parameters between the two types of tunnel diode (GaAs / GaAs) and (InGaP/GaAs) was studied. The parameters that have been compared are open-circuit voltage $\left(V_{O C}\right)$, efficiency $(\eta)$, the short circuit current density $\left(J_{S C}\right)$, and Fill Factor $(F F)$. Quite high operating factors for tandem cell are achieved by taking into account the crucial number of cells as well as improving layer parameters of the layers. All calculations and simulations of tandem cell are performed with the typical AM1.5 solar spectrum light intensity of 1 -sun at room temperature $(300 \mathrm{~K})$. Lastly, the findings illustrate that the optimum properties of the suggested tandem cell are efficiency $(\eta)=34.37$ percent, $V_{O C}=2.449 \mathrm{~V}, J_{S C}=21.69 \mathrm{~mA} / \mathrm{cm}^{2}, F F=89.33$ percent.
\end{abstract}

Keywords:

Dual junction, Solar cell, III-V Semiconductor Materials, Photovoltaic.

This is an open access article under the CC BY 4.0 license (http://creativecommons.org/licenses/by/4.0/). https://rengj.mosuljournals.com

\section{INTRODUCTION}

In the latest years, the requirement for renewable energy sources increased to decrease the emission of carbon dioxide and avoid using conventional energy sources such as Petrol, Coal, and Oil that pollutes the environment, which is why solar cells have invented and it is the most promising renewable energy [1]. One of the ways that used to harvest the sun's energy is by using the photovoltaic impact of solar cells to convert this energy to electricity. The multi-layer solar cell that used to collect a broad range of wavelengths is the most efficient used technology. Multi-layer solar cell structure (tandem) consisting of a number of single junction built of several materials that have different band gaps [2] [3]. The purpose of each layer is to gather a part of the solar spectrum (InGaP) and (GaAs) compounds are one of the main semiconductor materials used in the manufacture of tandem cells. (InGaP) is a semiconductor material with a large bandgap that is lattice-matched to GaAs and Ge [4], which makes it an ideal material for the upper cell of the tandem structure. The direct bandgap and high absorption rate are important properties of $\mathrm{InGaP}$ and $\mathrm{GaAs}$ [5] [6].The tandem cells are more efficient than their equivalents of a single layer [7]. Because of their high industrialization cost [8], these devices which extremely efficient are still confined to high cost applications, including space applications and high concentrated systems, Although their higher efficient compared to commonly accessible materials such as silicon cells. The Tandem solar cells were studied for the first time by the reference [9]. After that, in reference [10] Fan conducted tandem cell research based on computer analysis. In reference [11] Solar cells were built from the homogenous dual junction (DJ) by Hutchby in 1985. After that Lueck in 2006[12] was built a model of the dual-layer solar cell with a performance of $23.6 \%$. Then the tandem 
cell (GaInP/GaAs) was established at an efficiency of about $25.15, \mathrm{Jsc}=10.6 \mathrm{~mA} / \mathrm{cm} 2$, and $\mathrm{FF}=87.55 \%$ of these cells [6].By modifying the (BSF) layer of a dual-layer cell, other researchers attain an efficiency of $32.19 \%$ [13].

In this paper Silvaco, atlas software was used to simulate (InGaP/GaAs) cell and study the impact of multiple factors like thicknesses, and doping concentration level of layers in the (InGaP/GaAs) multi-layer solar cell on the parameters of solar cell shown, like, $(\mathrm{FF}),\left(\mathrm{V}_{\mathrm{OC}}\right)$, $\left(\mathrm{J}_{\mathrm{SC}}\right)$, and $(\eta)$.

\section{The simulation design of tandem cell}

\subsection{Tandem structure}

Silvaco Atlas TCAD is one of the more numerical simulator programs that bring results closed to reality. The tandem solar cell with high efficiency was simulated and optimized through the of the Silvaco program by using the theory driftdiffusion transport which is the basis of the tandem model. In addition, the main basic for designing the tandem cell is using the continuity equations, Poisson's equations and transportation equations [14]. These equations usually describe the conduct of the electron hole pair (EHP) because the of generation and recombination operation. Many models can be used to improve the structure of the modeled tandem cell. For example the Concentration Dependent Low Field Mobility model (CONMOB) designs a tandem solar cell for the low-field mobility of charge carriers that is based on doping, and other models like Optical Recombination (OPTR) ,(AUGER), and Shockley Read Hall (SRH) that are used for determining carrier generations and recombination. The statistics of Fermi-Dirac have been used for describing the carrier's action in thermal balance [15].

The tandem (InGaP/GaAs) structure is composed of (InGaP) as top cell and (GaAs) as a bottom cell and the GaAs tunnel diode is used to link the upper and lower cells of this model.

For better power harvesting [16], the band gap energy ( $\mathrm{Eg}$ ) of the top cell ( $\mathrm{InGaP})$ must be about $1.84 \mathrm{eV}$. This cell operate with high energy photons, and absorbs the majority of the wavelengths shorter and transmitted to the lower cell the long wavelengths this means lower cell operating with low energy photons, and the band gap energy (Eg) of the lower cell is around 1.42 to $1.43 \mathrm{eV} \mathrm{[17].} \mathrm{In} \mathrm{this}$ design, InAlGaP layers are used, as the window layer and back surface field (BSF) layer. Typically, the window layer is composed out of materials has a wide band gap, allowing a maximum solar irradiance to reach the device. The initial schematically structure for the simulated tandem are illustrated in Fig. 1. Moreover, Fig. 2 display the equivalent circuit for the suggested tandem cell.

\begin{tabular}{|c|c|c|c|}
\hline & & Anode Contact & \\
\hline $\begin{array}{l}0.03 \\
\mu \mathrm{m}\end{array}$ & window & $\mathrm{In}_{0.5}\left(\mathrm{Al}_{0.7} \mathrm{Ga}_{0.3}\right)_{0.5} \mathrm{P}$ & $\mathrm{P}=2 \mathrm{e} 18 \mathrm{~cm}^{-3}$ \\
\hline $\begin{array}{l}0.05 \\
\mu \mathrm{m}\end{array}$ & Emitter & $\mathrm{In}_{0.49} \mathrm{Ga}_{0.51} \mathrm{P}$ & $\mathrm{P}=2 \mathrm{e} 18 \mathrm{~cm}^{-3}$ \\
\hline $\begin{array}{l}0.55 \\
\mu \mathrm{m}\end{array}$ & Base & $\mathrm{In}_{0.49} \mathrm{Ga}_{0.51} \mathrm{P}$ & $\mathrm{n}=7 \mathrm{e} 16 \mathrm{~cm}^{-3}$ \\
\hline $\begin{array}{l}0.03 \\
\mu \mathrm{m}\end{array}$ & BSF & $\mathrm{In}_{0.5}\left(\mathrm{Al}_{0.7} \mathrm{Ga}_{0.3}\right)_{0.5} \mathrm{P}$ & $\mathrm{n}=2 \mathrm{e} 18 \mathrm{~cm}^{-3}$ \\
\hline $\begin{array}{c}0.025 \\
\mu \mathrm{m}\end{array}$ & $\begin{array}{l}\text { Tunnel } \\
\text { Diode }\end{array}$ & GaAs & $\mathrm{n}=5 \mathrm{e} 19 \mathrm{~cm}^{-3}$ \\
\hline $\begin{array}{c}0.025 \\
\mu \mathrm{m}\end{array}$ & $\begin{array}{l}\text { Tunnel } \\
\text { Diode }\end{array}$ & GaAs & $\mathrm{P}=3 \mathrm{e} 19 \mathrm{~cm}^{-3}$ \\
\hline $\begin{array}{l}0.04 \\
\mu \mathrm{m}\end{array}$ & window & $\mathrm{In}_{0.49} \mathrm{Ga}_{0.51} \mathrm{P}$ & $\mathrm{P}=3 \mathrm{e} 18 \mathrm{~cm}^{-3}$ \\
\hline $\begin{array}{l}0.50 \\
\mu \mathrm{m}\end{array}$ & Emitter & GaAs & $\mathrm{P}=2 \mathrm{e} 18 \mathrm{~cm}^{-3}$ \\
\hline $\begin{array}{l}2.00 \\
\mu \mathrm{m}\end{array}$ & Base & GaAs & $\mathrm{n}=2 \mathrm{e} 17 \mathrm{~cm}^{-3}$ \\
\hline $\begin{array}{l}2.10 \\
\mu \mathrm{m}\end{array}$ & BSF & $\mathrm{In}_{0.5}\left(\mathrm{Al}_{0.7} \mathrm{Ga}_{0.3}\right)_{0.5} \mathrm{P}$ & $\mathrm{n}=5 \mathrm{e} 18 \mathrm{~cm}^{-3}$ \\
\hline $\begin{array}{l}0.20 \\
\mu \mathrm{m}\end{array}$ & Substrate & GaAs & $\mathrm{n}=1 \mathrm{e} 18 \mathrm{~cm}^{-3}$ \\
\hline \multicolumn{4}{|c|}{ Cathode Contact } \\
\hline
\end{tabular}

Fig.1 schematically diagram of the simulated tandem cell.

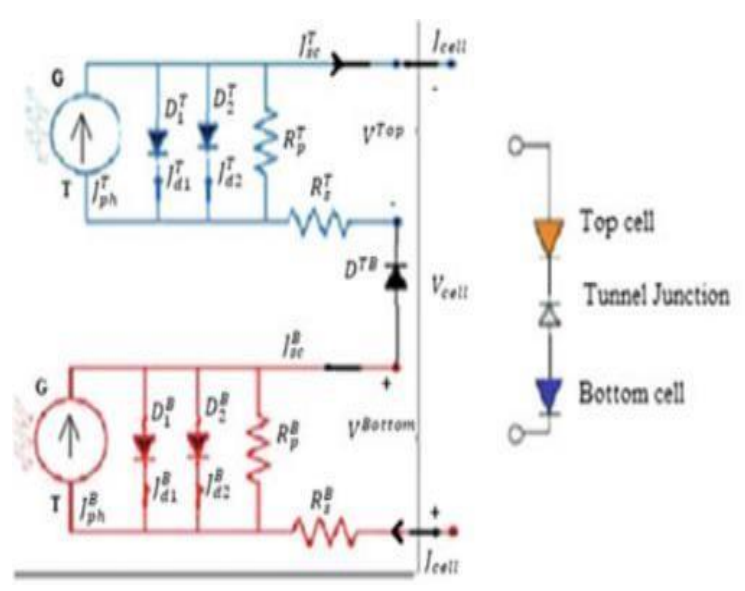

Fig.2 the equivalent circuit for the tandem modeling Proposed [18].

The equations that related to the equivalent circuit are illustrated as the following [18]:

Jcell $=\mathrm{Jph}-\mathrm{Jd} 1-\mathrm{Jd} 2-\frac{\mathrm{V}_{\text {cell }}+\mathrm{R}_{\mathrm{S}} \mathrm{J}_{\text {cell }}}{R_{P}}$ 


$$
\begin{aligned}
& \mathrm{J}_{\mathrm{ph}}(\mathrm{T}, \mathrm{G})=\frac{\mathrm{G}}{\mathrm{G} 0} \mathrm{~J}_{\mathrm{ph}} \mathrm{T}_{0} \mathrm{G}_{0}\left(1+\mathrm{C}_{\mathrm{J}_{\mathrm{ph}}}^{\mathrm{T}}\left(\mathrm{T}-\mathrm{T}_{0}\right)\right) \\
& J_{d 1}=J_{\text {sat } 1}(T)\left(\exp \frac{\mathrm{q}\left(\mathrm{V}_{\text {cell }}+\mathrm{R}_{\mathrm{S}} \mathrm{J}_{\text {cell }}\right)}{n_{1} K T}-1\right.
\end{aligned}
$$

Where $\mathrm{J}_{\text {cell }}$ is cell current density, $\mathrm{V}_{\text {cell }}$ is cell voltage, $\mathrm{J}_{\mathrm{dl}}$ is dark current density due to diffusion of minority carriers and recombination in the depletion region, $R_{S}, R_{P}$ is series and shunt resistance of the cell , $\mathrm{J}_{\text {satl }}$ is reverse saturation current density $\mathrm{n}$ is the ideality factor, $\mathrm{T}$ is the temperature and $\mathrm{G}$ is solar irradiance energy that received.

At $\mathrm{T}=300$ the current density through the two subcells must be equal to achieves current matching as shown in eq. 4 and the voltage of the cell is equal to the sums of subcells voltage and tunnel diode voltage in the cell as illustrated in eq.5

$$
\begin{aligned}
& \mathrm{J}_{\text {cell }}=\mathrm{J}_{\mathrm{SC}}^{\mathrm{B}}=\mathrm{J}_{\mathrm{SC}}^{\mathrm{T}} \\
& \mathrm{V}_{\text {cell }}=\mathrm{V}_{\mathrm{SC}}^{\mathrm{T}}-\mathrm{V}_{\mathrm{TB}}^{\mathrm{D}}+\mathrm{V}_{\mathrm{SC}}^{\mathrm{B}}
\end{aligned}
$$

\subsection{The impact of changing the thickness and doping density for the window layer of the top cell on the dual junction cell.}

The first layer in the solar cell that facing to the illumination is the window layer. InAlGaP is used as a window layer and BSF layer that features a wideband gap that permits optimal absorption in the photovoltaic device [19]. The existence of a window layer and a heavily doped region creates a potential barrier in the base region to surround the minority carriers in the region that lightly doped. To optimize the performance of the tandem cell, the first step is a variation the width of the window layer from 0.01 $\mu \mathrm{m}$ to $0.06 \mu \mathrm{m}$. The result show that the tandem cell's efficiency has a maximum value at a thickness of $0.02 \mu \mathrm{m}$ as given in Table 1. Figures 3-6 shows the impact of window thickness on the efficiency of the tandem cell, FF, Jsc, and Voc.

Table.1 Impact of changing the window layer width of the InGaP top cell on the significant factors of the tandem cell proposed.

\begin{tabular}{|c|c|c|c|c|}
\hline $\begin{array}{c}\text { Thickness } \\
(\boldsymbol{\mu m})\end{array}$ & $\begin{array}{c}\mathbf{J}_{\mathbf{S C}} \\
\left(\mathbf{m A} / \mathbf{c m}^{\mathbf{2}}\right)\end{array}$ & $\begin{array}{c}\text { Voc } \\
(\mathbf{V})\end{array}$ & $\begin{array}{c}\text { FF } \\
(\boldsymbol{\%})\end{array}$ & $\begin{array}{c}\text { Effi } \\
(\boldsymbol{\%})\end{array}$ \\
\hline 0.01 & 21.35 & 1.48 & 75.80 & 17.38 \\
\hline 0.02 & 21.20 & 2.45 & 89.19 & 33.59 \\
\hline 0.03 & 20.6 & 2.25 & 89.19 & 32.70 \\
\hline 0.04 & 20.03 & 2.44 & 45.88 & 16.41 \\
\hline 0.05 & 20.70 & 1.48 & 75.78 & 16.12 \\
\hline 0.06 & 20.17 & 1.48 & 75.75 & 15.85 \\
\hline
\end{tabular}

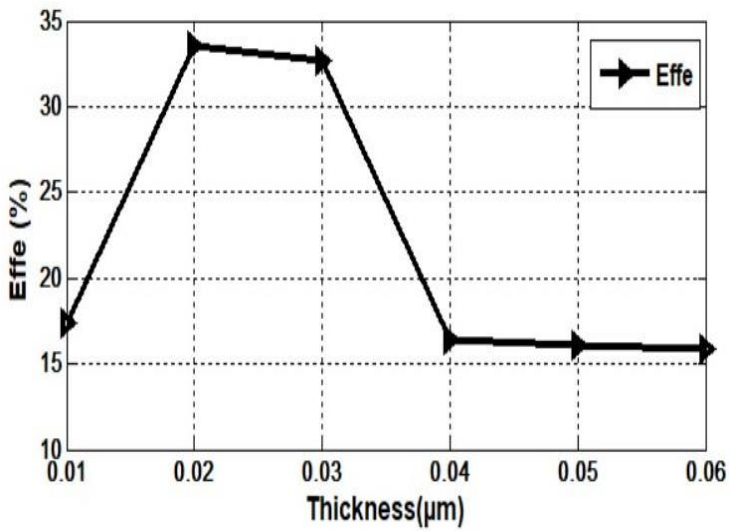

Fig. 3 The variation Impact of window layer thickness on the efficiency.

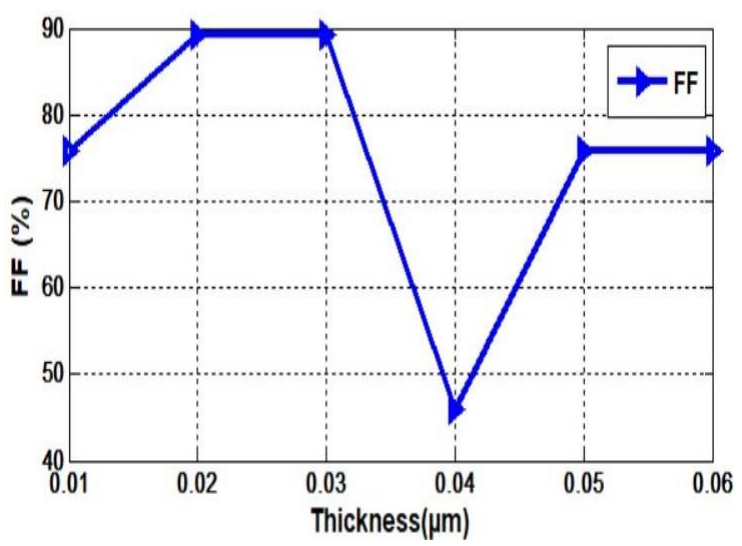

Fig. 4 The variation Impact of window layer thickness on the Fill Factor.

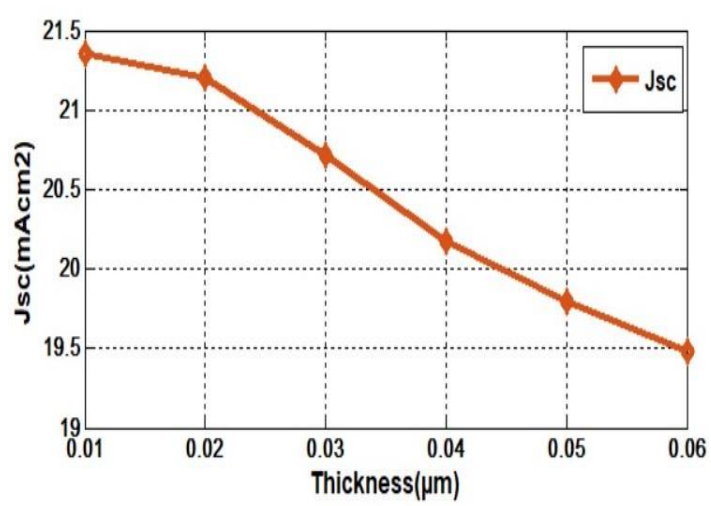

Fig. 5 The variation Impact of window layer thickness on the short-circuit current density. 


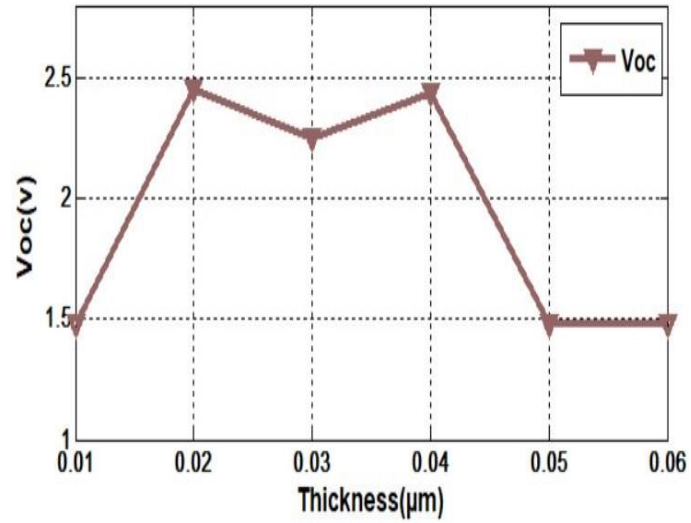

Fig. 6 The variation Impact of window layer thickness on the open circuit voltage.

The second step is changing the window layer doping density from $\left(\mathrm{Na}=2 \mathrm{e} 18 \mathrm{~cm}^{-3}\right.$ to $\mathrm{Na}=$ $1 \mathrm{e} 18 \mathrm{~cm}^{-3}$ ), reduce doping concentration results to enhancement the efficiency and make it equal to $34.24 \%$. Figures 7-10 illustrates the impact of variation of the doping density of the top cell window layer versus on the efficiency of the tandem cell, FF, $\mathrm{J}_{\mathrm{SC}}$, and $\mathrm{V}_{\mathrm{OC}}$.

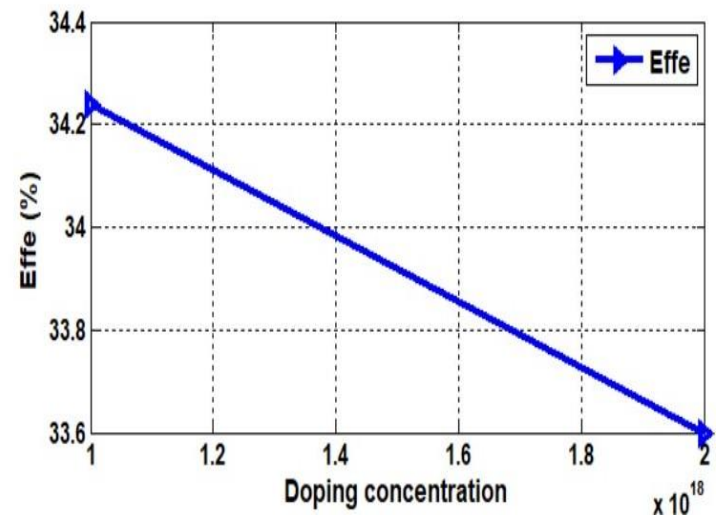

Fig. 7 The window layer doping concentration variation effect on the efficiency.

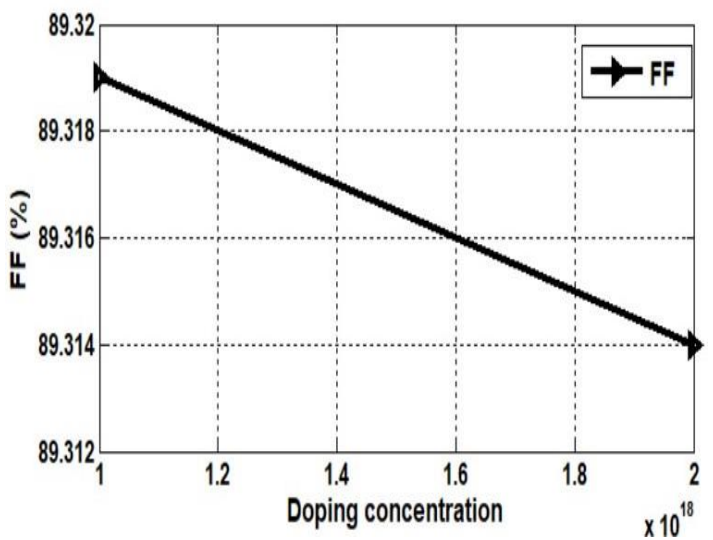

Fig. 8 The window layer doping concentration variation effect on the Fill Factor

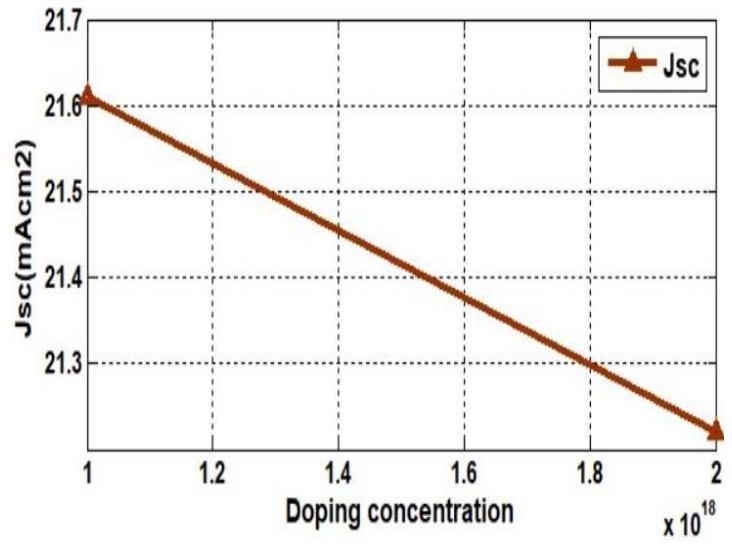

Fig. 9 The window layer doping concentration variation effect on Short-circuit current density.

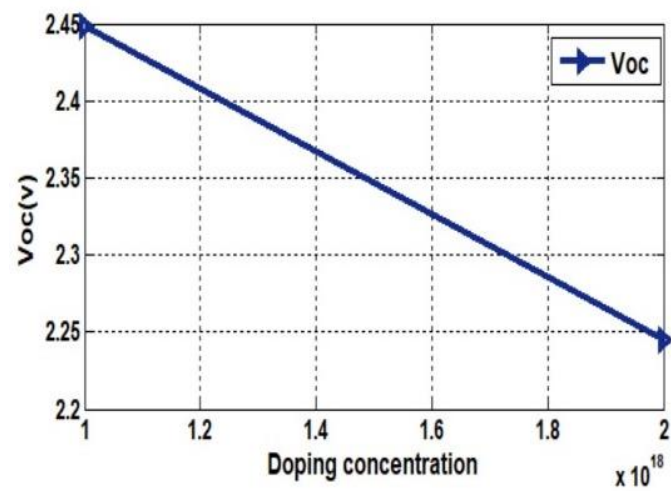

Fig. 10 The window layer doping concentration variation effect on the open circuit voltage

\subsection{Tunnel junction (GaAs) modeling:}

A serial electric connection of the sub cells is necessary for the solar multi-layer cell. The tunneling diode is put into an inverse polarization between the two cells [13] (see Fig. 11). (a)

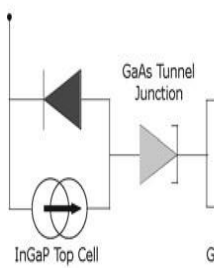

InGaP Top Cell

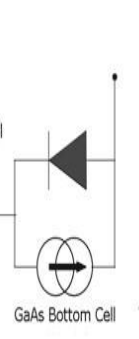

(b)

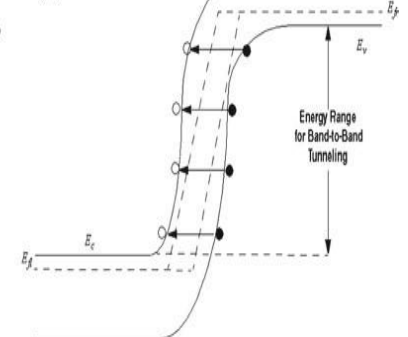

Fig.11 (a). Tandem solar cell equivalent circuit, (b). Tunnel band diagram [13]. 
The less optic and electrical loss must be used in links. This is why the best choice is to build a tunnel intersection with a high impurity concentration [20]. The temperature has a great effect on the performance of the cell if the tunnel junction has lower doping [21], [22], and [23]. Increasing the bandgap of the junction will improve the performance of the cell [24]. As a result, GaAs is being utilized as a tunnel diode since it has lower optical absorption and lowers series resistance trajectory among the upper cell (BSF) layer and the window layer of the lower cell as display in Fig 1 . Which decreases the length of the depletion region and increase the tunneling phenomena and electrons can cross the depletion region easily [18].

\subsection{Change in the tunnel junction}

The tunnel junction thickness usually determines the path of electrons whether it has high or low resistance between the upper's BSF layer and the window layer of the lower cell[4] the links must show a simple path between the two cells in order to have a small loss as minimum as possible. In order to achieve this low path during the tunnel junction, the impurity concentration must be increased, and the bandgap of the tunnel junction must have a large value [4] [18].The impact of the change in the tunnel junction's materials on the tandem cell is gives in Table 2. The performance of the InGaP/GaAs tunnel diode is best from the performance of the GaAs /GaAs tunnel diode because InGaP/GaAs tunnel diode has a large current (tunneling) compared to GaAs /GaAs tunnel diode. Also, InGaP material more transparency than GaAs because it's large band gap, which leads to improving the overall performance of the cell.

Table 2. The impact of changing the tunnel junction's materials on the suggested tandem cell characteristics.

\begin{tabular}{|c|c|c|c|c|}
\hline $\begin{array}{c}\text { TJ } \\
\text { materials }\end{array}$ & $\begin{array}{c}\text { Jsc } \\
\left(\mathbf{m A} / \mathbf{c m}^{\mathbf{2}}\right)\end{array}$ & $\begin{array}{c}\text { Voc } \\
(\mathbf{V})\end{array}$ & $\begin{array}{c}\text { FF } \\
(\boldsymbol{\%})\end{array}$ & $\begin{array}{c}\text { Eff } \\
(\%)\end{array}$ \\
\hline $\mathbf{G a A s} / \mathbf{G a A s}$ & 21.614 & 2.448 & 89.31 & 34.24 \\
\hline InGaP/GaAs & 21.690 & 2.449 & 89.33 & 34.37 \\
\hline
\end{tabular}

\section{Results and discussion}

The structure of the suggested tandem cell as simulated in SILVACO ATLAS are shown in Fig. 12.

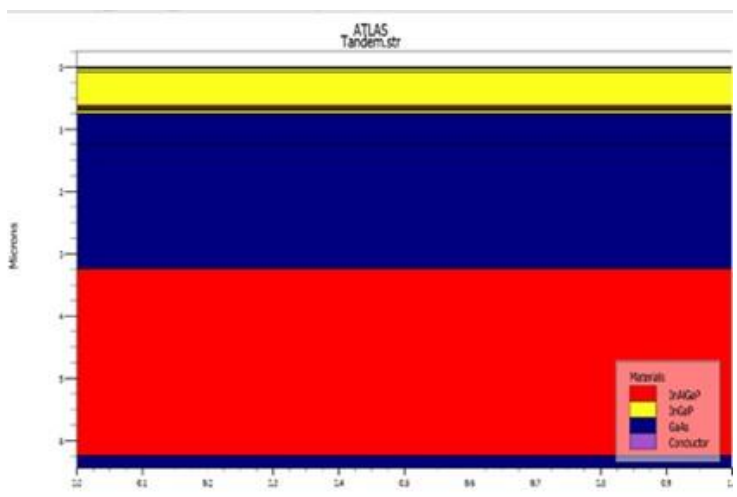

Fig.12 The tandem cell proposed structure.

The anode is located at the top of the structure, while the cathode is located at the bottom. The mesh grid upon which the equipment is designed is the first factor selected in this simulation. In order to define the device's structure, a mesh grid has horizontal and vertical lines with user-specified spacing. This cell's area is determined by forming a series of triangles. Results are more exact when the meshes are smaller. The solar cell's electrical properties are assessed at each cross for horizontal and vertical lines specified in the mesh to determine the overall performance of the solar cell. The device's mesh construction is depicted in Fig. 13, and the doping profile is depicted in Fig.14.

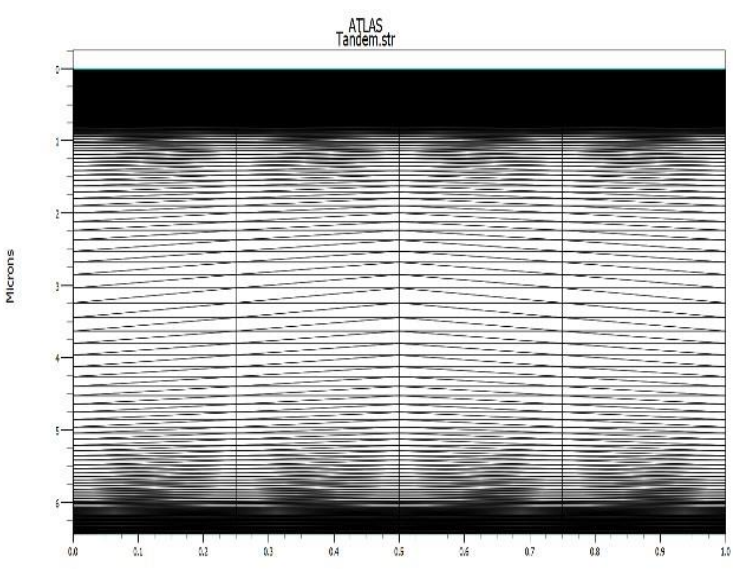

Fig.13 Mesh profile of the designed structure.

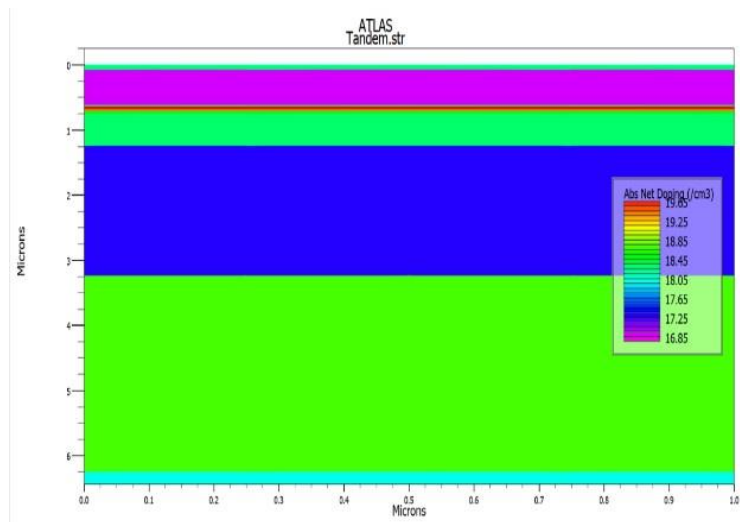


Fig .14 Doping profile of the proposed cell.

The spectral response of photocurrent sources, accessible photocurrent, and cathode current is another significant parameter giving an idea of photon absorption. The standard AM1.5 spectrum is used as a radiation intensity source to illuminate the simulated tandem cell as shown in Fig 15.

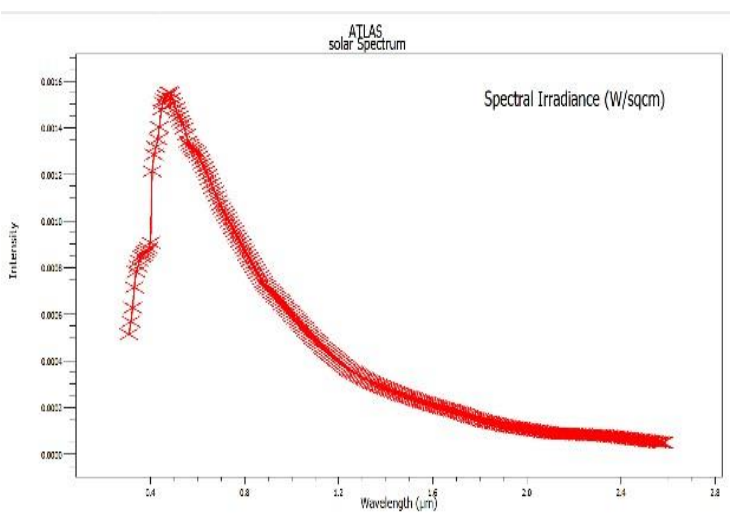

Fig.15 The standard spectrum AM1.5

The models such as CONMOB, SRH, and, BGN are used in this modeling.

- CONMOB: standard concentration dependent mobility model.

- SRH: Shockley-Read-Hall recombination.

- BGN: band-gap narrowing.

The design emulates the performance of tandem cells under the conditions of standard AM 1.5 spectrum (1 sun). The suggested cell's (I-V) characteristics curve is drawn in Fig.16.

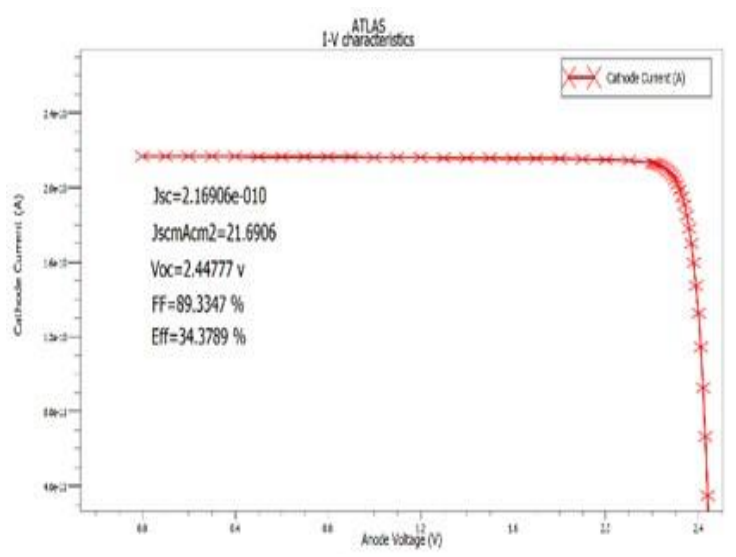

Fig.16 (I-V) characteristics curve of the suggested cell.

Lastly, a comparison between main parameters of the proposed tandem structure with other works is exhibits in Table 3.
Table 3 Comparison between the proposed structure with other works.

\begin{tabular}{|c|c|c|c|c|}
\hline $\begin{array}{c}\text { Tandem } \\
\text { cells }\end{array}$ & $\begin{array}{c}\mathrm{JSC}_{\mathrm{SC}} \\
\left(\mathrm{mA} / \mathrm{cm}^{2}\right)\end{array}$ & $\begin{array}{c}\text { Voc } \\
(\mathrm{V})\end{array}$ & $\begin{array}{c}\text { FF } \\
(\%)\end{array}$ & $\begin{array}{c}\text { Effi } \\
(\%)\end{array}$ \\
\hline $\begin{array}{c}\text { InGaP/GaAs } \\
{[12]}\end{array}$ & 10.9 & 2.32 & 79.00 & 23.6 \\
\hline $\begin{array}{c}\text { InGaP/GaAs } \\
{[6]}\end{array}$ & 10.6 & 2.30 & 87.55 & 25.14 \\
\hline $\begin{array}{c}\text { InGaP/GaAs } \\
{[13]}\end{array}$ & 16.1 & 2.39 & 87.52 & 32.196 \\
\hline $\begin{array}{c}\text { Proposed } \\
\text { structure }\end{array}$ & 21.69 & 2.44 & 89.33 & 34.37 \\
\hline
\end{tabular}

As seen from above table, a high conversion efficiency of $34.37 \%$ is achieved compared to previous structures.

\section{CONCLUSION}

SILVACO ATLAS TCAD program is utilized for designing and simulating a multi-layer solar cell (InGaP/GaAs) structure. The two cells, $\mathrm{InGaP}$ and GaAs, form this tandem cell. The optimization process of the proposed structure was performed by modifying the doping concentration, and the thickness of the window layer of the top cell. The material (InAlGaP) is studied as a solar cell absorber layer in this paper, and it is remains considered a promising solar cell material. Firstly, the thickness and doping concentration of the window layer of the top cell on the tandem cell is improved .The results show that in the event of a decrease in the thickness of the window layers the efficiency is rising. In addition, in this simulation by changing the doping concentration the efficiency improved. Lastly, we notice through changing the tunnel junction, the efficiency increases too. The tandem model demonstrates a good improvement in significant properties of the solar cell because of more transparency created in the junction of the tunnel, and the collection of more carriers. The obtained results from the dual junction cell are, $(\mathrm{JSc})$ of $(21.69 \mathrm{~mA} / \mathrm{cm} 2)$, and (Voc) is $(2.44 \mathrm{~V}) \mathrm{FF}$ is $89.33 \%$, and $(\eta)$ is about $(34.37 \%)$. All the findings of this research were performed under standard AM1.5 illumination. Finally, in comparison with recent studies, the proposed structure has a better result. 


\section{References}

[1] L. Byrnes, C. Brown, J. Foster, and L. D. Wagner, "Australian renewable energy policy: Barriers and challenges," Renew. Energy, vol. 60, pp. 711-721, 2013.

[2] D. Benmoussa, F. Mostefa, and D. Tidjani,

[3] "Performance comparison of (GaAS/GaAs) and (InGaP/GaAs) tunnel junction in multi-junction solar cells,"5th Int. Conf. Power Gener. Syst. Renew. Energy Technol. PGSRET 2019, pp. 14, 2019.

[4] N. Shigekawa, R. Kozono, S. Yoon, T. Hara, J. Liang, and A. Yasui, "Effects of post bonding annealing on $\mathrm{GaAs} / / \mathrm{Si}$ bonding interfaces and its application for sacrificial-layer-etching based multi- junction solar cells," Sol. Energy Mater. Sol. Cells, vol. 210, 2020.

[5] P.P. Nayak, J.P. Dutta, and G.P. Mishra, "Efficient InGaP/GaAs DJ solar cell with double back surface field layer," Eng. Sci. Technol. Int. J., vol.18 no.3, p.p. 325-335, 2015.

[6] L. Bouzid, L. Dehimi, F. Pezzimenti, M. Hadjab, and A.H. Larbi, "Numerical simulation study of a high efficient AlGaN-based ultraviolet photodetector," Superlattices Microstruct, vol. 122, p.p. 57-73, 2018.

[7] J. Leem, Y. Lee, and J. Yu, "Optimum design of InGaP/GaAs dual-junction solar cells with different tunnel diodes," Opt. Quant. Electron, vol. 41no. 8, p.p. 605-612, 2009.

[8] A. Reinders, P. Verlinden, and W. van Sark, "Photovoltaic Solar Energy: From Fundamentals to Applications," First Edition, 2017.

[9] R. Oshima, Y. Shoji, K. Makita, A. Ubukata and T. Sugaya, "High Doping Performance of Sulfur and Zinc Dopants in Tunnel Diodes Using Hydride Vapor Phase Epitaxy," in IEEE Journal of Photovoltaics, vol. 10, no. 3, pp. 749-753, May 2020.

[10]M. Wolf,"Limitations and Possibilities for Improvements of Photovoltaic Solar Energy Converters," Solar Energy, vol. 4 no. 4, p. 41, 1960.

[11] J. Fan, B. Tsaur, and B. Palm, "Optimal Design of High-Efficiency Tandem Cells," 16th Photovoltaic Specialists Conference, p.p. 692701, 1982.

[12] J. Hutchby, R. Markunas, and S. Bedair, "Material Aspects of the Fabrication of Multijunction Solar

[13] Cells," Photovoltaics, vol. 543. p.p. 40-61, 1985.

[14] M. Lueck, C. Andre, A. Pitera, M. Lee, E. Fitzgerald, and S. Ringel, "Dual Junction GaInP/GaAs solar cells grown on metamorphic $\mathrm{SiGe} / \mathrm{Si}$ substrates with high open circuit voltage," IEEE Electron Device Letters, vol. 27 no.3, p.p. $142-44,2006$.

[15] K. Singh, and S. Sarkar, "highly efficient ARC less InGaP/GaAs DJ solar cell numerical modeling using optimized InAlGaP BSF layers," Opt Quant Electron, vol. 43, p.p. 1-21, 2012.

[16] K. Mohammed, "High Efficiency Tandem Solar Cell based on $\mathrm{InGaP}$ and $\mathrm{GaAs}$ for Sustainable Energy
[17] Applications," International Journal of Computer Applications, vol. 181, p. 0975 8887, 2018.

[18] I. Tinedert, A. Saadoune, I. Bouchama, and M. Saeed, "Numerical modelling and optimization of $\mathrm{CdS} / \mathrm{CdTe}$ solar cell with incorporation of Cu2O HT-EBL layer," Opt. Mater. (Amst), vol. 106, p. 109970, 2020.

[19] D.Friedman, J.Olson and S. Kurtz, "High efficiency III-V Multijunction Solar Cells", Second Edition, Handbook of Photovoltaic Science and Engineering, , p. 329, 2011.

[20] B.Roberto, T.Santiago, and M.Arturo, "Design of Two and Four-Terminal InGaP/GaAs//Si Tandem Solar Cells", Conference Record of the IEEE Photovoltaic Specialists Conference, pp. 989-993, 2019.

[21] P. Pandey, A. Bhatnagar, and V. Janyani, "Multijunction solar cell based on efficient IIIV InGaP/GaAs with GaInAsp as BSF layers," Springer Singapore, vol. 546, 2020.

[22] H. Arzbin and A. Ghadimi, "Improving the performance of a multi-junction solar cell by optimizing BSF, base and emitter layers," Mater. Sci. Eng. B Solid-State Mater. Adv. Technol., vol. 243, pp.

[23] 108-114, 2019.

[24] G. Sahoo and G. Mishra, "Effect of Wideband Gap Tunnel Diode and Thickness of the Window Layer on the Performance of a Dual Junction Solar Cell," Procedia Technol., vol. 25, pp. 684691, 2016.

[25] J. Lavery, S. Reader, and T. Weatherford, "Quantum

[26] Tunneling Model of a PN Junction in Silvaco", Edocs.Nps.Edu, no. September 2008.

[27] E. Kane, "Theory of tunneling", J. Appl. Phys., vol. 32, no. 1, pp. 83-91, 1961.

[28] J. Hauser, Z. Carlin, and S. Bedair, "Modeling of tunnel junctions for high efficiency solar cells", Appl. Phys. Lett., vol. 97, no. 4, pp. 1-4, 2010.

[29] G. Sahoo, P. Nayak, and G. Mishra, "Design and evaluation of ARC less InGaPGaAs DJ solar cell with InGaPtunnel junction and optimized double top BSF layer", Superlattices Microstruct., vol. 95, pp. 115- 127, 2016. 


\section{محاكاة الخلايا الثمسية الترادفية عالية الكفاعة باستخدام (InGaP / GaAs)}

خالا خليل محمد

khalid.khaleel@uoninevah.edu.iq
مروه ماهر سالم

marwa.salim20192019@stu.uoninevah.edu.iq

$$
\text { جامعة نينوى - قسم هندسة الالكترونيك -موصل/العر اق }
$$

يعتمد هيكل خلية الوصلة المزدوجة) التر ادفية ( (InGaP / GaAs) على فوسفيد الإنديوم الغاليوم (InGaP)كخلية عليا، وأرسينيد

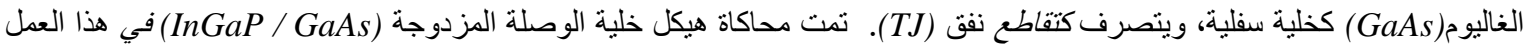

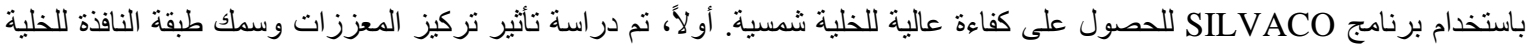

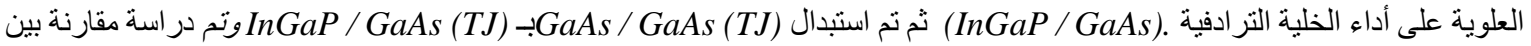

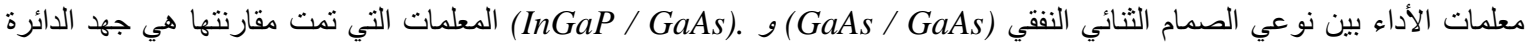

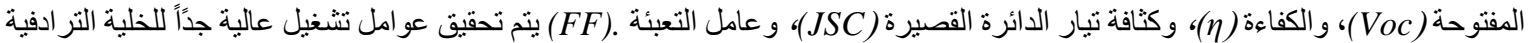

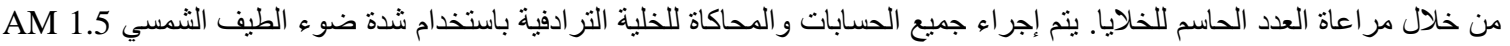

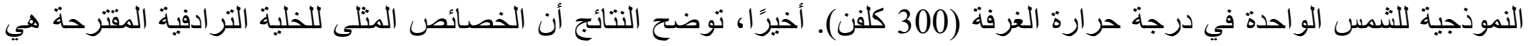

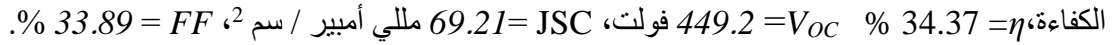

$$
\text { الكلمع مزدوجة الدالة: خلايا شمسية، مواد أشباه الموصلات III-V، كهروضوئية. }
$$

